\title{
Teacher Trainees Perception Of Educational Games In Teaching Classification Of Living Organisms In Colleges Of Education In Ghana
}

\author{
Joseph Parker *, Valentina Osei-Himah ${ }^{* *}$ \\ * Enchi College of Education, P. O. Box 44, Enchi. W/R- Ghana. \\ ${ }^{* *}$ Atebubu College of Education, P. O. Box 29, Atebubu. B/A \\ DOI: 10.29322/IJSRP.11.06.2021.p11430 \\ http://dx.doi.org/10.29322/IJSRP.11.06.2021.p11430
}

\begin{abstract}
The purpose of the study was to explore the perceptions of teacher trainees on the use of educational games in teaching and learning of classification of living organisms. The study adopted the quantitative approach. Inferential statistics was used to report the results of the study. Frequency counts and percentages were used to report the teacher trainees' perceptions about the impact of game-based learning approach in the teaching and learning of classification of living organisms. The study was carried out in Enchi College of Education in the Aowin Municipality in the Western North Region of Ghana. Stratified, simple random and systematic sampling techniques were used to select 80 respondents for the study. This was made up of 30 level 300, 30 level 200 and 20 level 100 students respectively. Thus 30 level 300, 30 level 200 and 20 level 100 participants were subjected to game-based learning approach as a group.

The instrument used for the data collection was questionnaire guide. The findings of the study revealed that, the game-based learning approach motivate and engage, provide immediate feedback, develop social and physical skills simultaneously, help students to learn with fun and increase students interest and confidence level.
\end{abstract}

Index Terms- educational games; game-based learning; pedagogical devices; concept; perceptions.

\section{INTRODUCTION}

$E^{d}$ ducational games are sets of competitive activities which consist of strict rules to reach desired goals such as acquiring or improving knowledge and skills (Boctor, 2012; Haggart, 2001; Webb, Simpson, Denson and Duthie, 2012). They differ from noneducational games where the purpose is primarily on entertainment. Educational games are innovative teaching tools that have been shown to promote critical thinking, enhance clinical confidence building and promote problem solving skills (Anyanwu, 2014).

According to Hughes (1999), playing is different from learning and working. Playing is an activity that helps to achieve complete development, both physically, intellectual, social, moral, and emotional. Teacher-trainees therefore need to be exposed to game-based learning approach so as to inculcate in them the competence and culture in using educational games in their teaching. Hurlock (1978) opines that a game is a process of physical or physic activity that is fun and enjoyable. This assertion is being supported by Andang (2006) who contended that through playing activity, children can acquire learning that consists of cognitive, social, emotion, and physical development aspects. Wright (1984) also said that playing games, is a good way to learn vocabulary, especially in language and science classes or lessons. Generally, game-based learning is designed to balance subject matter with gameplay and the ability of the player to retain and apply the subject matter to the real world. It can be said that playing and learning are synonymous, leading to cognitive and emotional development inside a social and cultural context, for instance, the game of hide and seek. Thus, in such a game, good hiders need visual and spatial perspective to define the best hiding places while seekers must be skilled at searching for cues from the surroundings and choosing the most probable location for the hider among various possible places (Bhoopathi, Sheoran and Välimäki, 2006) In a successful game-based learning environment, choosing actions, experiencing consequences, and working toward goals allows players to make mistakes through experimentation in a risk-free environment (Green and Bavelier, 2012). Games have rules and structure and goals that inspire motivation. Most games also have problem-solving situations that spark creativity (Kim, Park and Baek, 2009). One remarkable thing about educational games is that they remove much of the intimidation inherent in the learning process.

Educational games make learning concepts more palatable for students and supply learner with a platform for their creative thoughts to bounce around. Games encourage creative behaviour and divergent thought (Fuszard, 2001).

As pedagogical devices, games are extremely useful and are effective for dealing with problem solving and key concepts in the teaching and learning of science. it also encourages collaborative problem-solving skills. Using games provide easy means to incorporate peer learning aid with high concentration levels. The highly adaptable, flexible nature of games can be molded to suit a variety of learning settings and environments. Apart from inviting students to learn curriculum content in a fun and relaxed manner, games also expose students to other skills development during game play via sequential, verbal, visual and kinetic and other game-based activities (Fuszard, 2001). Games are flexible pedagogical tools which expose students and staff to other inherent skills. 
An educational game is a game designed to teach humans about a specific subject and to teach them a skill. Games are interactive play that teach us goals, rules, adaptation, problem solving, interaction, all represented as a story. They satisfy our fundamental need to learn by providing enjoyment, passionate involvement, structure, motivation, ego gratification, adrenaline, creativity, social interaction and emotion in the game itself while the learning takes place (Fuszard, 2001). Games allow students to go beyond information found in books, brings new ideas, develop social competencies and build the foundations for teamwork. Games provide opportunity for teachers to improve the effectiveness of the teaching process. They allow for increasing involvement of students and are efficient in overcoming significant deficits of traditional teaching methods (Kapp, 2012; Sheldon, 2012). It can therefore be deduced from the above literature that educational games are seen as entertainment rather than a method of learning since games have rules, definitive objectives, measurable goals and provide an interactive experience that promotes a sense of achievement for all participants which tend to motivate and engage students, give immediate feedback, promote cognitive growth and enhance skills development.

\section{REVIEW OF LITERATURE}

\section{Perceptions about the use of game-based learning approach}

Learning through games is not a new phenomenon. According to Bradshaw and Lowenstein (2007) the use of games for learning is a rather ancient technique, for example, games were used to coach soldiers for war. Ibrahim, Yusoff, Omar and Jaafar (2011) undertook a study to investigate the perception of Malasyian students towards usage of online educational games for their learning. Results showed that most students were fascinated with the idea of using games for learning with all of them believing that learning with games can be fun, most of them believe games can help them to do better in their learning as well as can make learning more interesting. This suggests that students have positive perceptions about the use of educational games in learning. Further research is needed to unveil the situation in the Ghanaian context especially among teacher trainees.

Jenkins, Klopfer, Squire and Tan (2003) argued that traditional pedagogical tools such as lectures, discussions, laboratory reports, homework, field trips, tests, and textbooks can be positively augmented using games. Gee (2008) stated that a good game helps in deeper learning. Gee (2008) was emphatic that the use of games makes students think like scientists. A welldesigned instructional game can engage students in the learning process. This can be done through the use of virtual environments that provide students with scenarios where they can engage in problem-solving activities, and therefore enhance learning (Ibrahim et al, 2011).

Studies have found that using educational games as a learning approach can promote the holistic learning of students including cognitive, affective as well as psychomotor skills (Garris, Ahlers, \& Driskell, 2002). A study by Garzotto (2007) revealed that multiplayer online games provided learning benefits on affective level as well as knowledge domain. Students were found enjoying the games, always engaged, motivated, and excited during the game play session. Educational games encompass a wide range of activities that can support playing, entertainment and learning, teaching on many disciplines. Studies by (Lieberman, 2001), (Virvao, 2005), (Hill, 2006), and (Sugimoto, 2007) confirm that game motivates learning, offer immediate feedback, support skills, and influences changes in behavior and attitudes.

From the above, it can be deduced that there is a positive perception about the impact of educational games on the learning process.

The study focused on how teacher trainees perceive gamebased learning approach as teaching strategies Colleges of Education in Ghana. The reason is that there has been little or no study conducted on teacher trainee's perception of game-based learning approach in Colleges of Education in Ghana. This study however wants to explore the perceptions of teacher trainees on the use of game-based learning approach as teaching strategy using teacher trainees in Enchi College of Education in the Aowin Municipality in the Western North Region, Ghana.

The study specifically sought to explore the perceptions of teacher trainees on the use of game-based learning approach in teaching and learning of Classification of living organisms in Enchi College of Education in Ghana.

\section{RESEARCH QUESTION}

The research question that enable the researchers gather relevant information for the study was: What are the perceptions of teacher trainees on the use of game-based learning approach in teaching and learning of Classification of living organisms in Enchi College of Education in Ghana?

\section{METHODOLOGY}

The study adopted the quantitative approach. Both descriptive and inferential statistics were used to report the results of the study. Frequency counts and percentages were used to report the teacher trainees' perceptions about the impact of gamebased learning approach. For simplicity and clarity, results were presented in tables.

The data collected on game-based learning approach by the researchers through questionnaire guide was analysed by the use of SPSS version 21.0 based on the themes arrived at in the data collection. The data analysis was guided by the research questions for the study.

The population of the study were teacher trainees in Enchi College of Education in Ghana. stratified, simple random and quota sampling technique were used to sample eighty (80) respondents. This was made up of forty (40) male teacher trainees and forty (40) female teacher trainees.

The research instrument used to gather data for the study was self-designed questionnaire guide titled Perception of Teacher Trainees on the Use of Game-based Learning Approach a based on the topic treated. It was divided into two sections. Section A had six questionnaire guide items 1-6) and Section B had four items (7-10). The responses to the items were in five Likert options of strongly agree, agree, neutral, disagree and strongly disagree. 
The content validity of the test was ascertained by subjecting the instrument to the scrutiny by colleagues. The instrument was pilot-tested to ascertain its validity and reliability index.

\section{Pre-intervention}

Prior to the implementation, the participants were asked to write down their expectations for the use of game-based learning approach. This enabled the researchers to verify whether their expectations have been met after the treatments were given.

\section{Intervention}

Educational games were used by the researcher to teach the participants. In all, the whole lesson was taught in two weeks made up of 12 hours was used to teach the participants classification of living organisms. When designing the games, particular attention was paid to the General Biology Course objectives and the appropriateness of the game to the teacher trainees' level. Necessary changes were made to the games based on the feedback received from experts and colleagues. The educative card game and descriptive game were used to teach participants.

The researchers explained and played the game as an example in order for the students to understand the game.

\section{Post-intervention}

After the treatment, the questionnaire guide on game-based learning approach were administered to participants through some selected teachers, and retrieved through same teachers. This was done to ensure high coverage, completion, and return rate.

\section{RESULTS AND DISCUSSIONS}

Table 1a: Perception of Teacher Trainees on the Use of Game-based Learning Approach in Teaching and Learning of Classification of Living Organisms

\begin{tabular}{|c|c|c|c|c|c|c|c|}
\hline & \multirow[t]{2}{*}{ Statement } & \multirow[b]{2}{*}{$\begin{array}{l}\text { trongly } \\
\text { gree (SA) }\end{array}$} & \multicolumn{2}{|c|}{ Responses } & \multirow[b]{2}{*}{$\begin{array}{l}\text { Disagree } \\
\text { (D) }\end{array}$} & \multirow[b]{2}{*}{$\begin{array}{l}\text { Strongly } \\
\text { Disagree (SA) }\end{array}$} & \multirow[t]{2}{*}{ Total } \\
\hline & & & $\begin{array}{l}\text { Agree } \\
\text { (A) }\end{array}$ & $\begin{array}{c}\text { Neutral } \\
(\mathbf{N})\end{array}$ & & & \\
\hline 1 & $\begin{array}{l}\text { Game-based learning motivated } \\
\text { and engaged me during teaching } \\
\text { and learning process }\end{array}$ & 62 & 10 & 3 & 3 & 2 & 80 \\
\hline 2 & $\begin{array}{l}\text { Game-based learning provided } \\
\text { immediate feedback to me }\end{array}$ & 52 & 20 & 4 & 2 & 2 & 80 \\
\hline 3 & $\begin{array}{l}\text { Game-based learning helped me } \\
\text { to develop social and physical } \\
\text { skills simultaneously }\end{array}$ & 61 & 16 & 3 & 0 & 1 & 80 \\
\hline 4 & $\begin{array}{l}\text { Game-based learning enabled } \\
\text { me to learn with fun }\end{array}$ & 34 & 40 & 1 & 3 & 2 & 80 \\
\hline 5 & $\begin{array}{l}\text { Game-based learning increased } \\
\text { my interest in the lesson }\end{array}$ & 30 & 46 & 2 & 1 & 1 & 80 \\
\hline 6 & $\begin{array}{l}\text { I felt confident in my abilities in } \\
\text { the topic when game-based } \\
\text { learning approach was used for th } \\
\text { lesson delivery }\end{array}$ & & 36 & 0 & 2 & 2 & 80 \\
\hline
\end{tabular}

Table 1a reveals that, 62 respondents strongly agreed that game-based learning approach motivated and engaged them during teaching and learning process, 10 respondents agreed that game-based learning approach motivated and engaged them during teaching and learning process. However, 3 respondents responded neutral on whether game-based learning approach motivated and engaged them during teaching and learning process while 3 disagreed that game-based learning motivated and engaged them during teaching and learning process and 2 respondents strongly disagreed that game-based learning motivated and engaged during teaching and learning process. Thus, the responses gathered from the majority 72 of the respondents confirmed the assertion of Norizan (2003), that educational games help increase student motivation.

Out of the 80 respondents 52 respondents strongly agreed that game-based learning approach provided immediate feedback to them during teaching and learning process. 20 respondents agreed that game-based learning approach provided immediate feedback to them during teaching and learning process. Again, 4 respondents views on whether game-based learning approach provided immediate feedback to them was neutral while 2 respondents disagreed and 2 strongly disagreed respectively that game-based learning provided them immediate feedback during teaching and learning process. Thus, the responses gathered from the majority 72 who strongly agreed and agreed respectively was in agreement with the assertion of Lieberman, (2001), Virvao, (2005), Hill, (2006), and Sugimoto, (2007) when they said that game motivates learning, offer immediate feedback, support skills, and influences changes in behavior and attitudes as indicated in the literature review. From Table 1a, 61 out of 80 respondents strongly agreed that game-based learning helped them to develop social and physical skills simultaneously. Also, 15 respondents 
agreed that game-based learning helped them to develop social and physical skills simultaneously, 3 respondents responded neutral to the statement that game-based learning approach helped them to develop social and physical skills simultaneously, no respondent disagreed that game-based learning approach helped them to develop social and physical skills simultaneously. However, 1 respondent strongly disagreed that game-based learning approach helped them to develop social and physical skills simultaneously respectively. The responses given by the majority 76 of the respondents affirmed that game-based learning approach has helped them to develop social and physical skills simultaneously. This view was supported by Bainbridge, (2007) when he said that today's games are more social and that with most teens playing games with others, can incorporate many aspects of civic and political life as indicated in the literature review.

Table 1a further reveals that out of 80 respondents, 34 strongly agreed that game-based learning enabled them to learn with fun. 40 respondents agreed that game-based learning enabled them to learn with fun and 1 respondent remained neutral on the assertion that game-based learning enabled them to learn with fun. However, 3 respondents disagreed and 2 strongly disagreed that game-based learning enabled them to learn with fun respectively. The responses derived from the respondents above suggest that game-based learning approach enabled them to learn with fun. This view is supported by Ibrahim et al (2011) when they said that most students were fascinated with the idea of using games for learning with all of them believing that learning with games can be fun. This same view was also shared by Hurlock, (1978) who asserted that a game is a process of physical or physic activity that is fun and enjoyable.

On the opinion of the respondents on whether game-based learning has increased their interest or not, 30 respondents strongly agreed and 46 respondents agreed that game-based learning has increased their interest. However, 2 respondents indicated neutral in their response whiles 1 respondent disagreed and 1 respondent strongly disagreed that game-based learning has increased their interest. A cursory look at this response indicates that majority 76 of the respondents confirmed that game-based learning approach has increased their interest in the lesson. This assertion is supported by Ibrahim et al (2011) who opined that the used of game-based learning approach in the teaching and learning of science can help students to do better in their learning as well as making learning more interesting.

Table 1a again reveals that, 40 respondents strongly agreed that game-based learning approach helped them to feel confident in their abilities in classification of living organisms when gamebased learning approach was used to deliver the lesson. Also, 36 respondents agreed that game-based learning approach helped them to feel confident in their abilities in classification of living organisms when game-based learning approach was used to deliver the lesson. None of the respondent responded neutral to the statement that game-based learning approach helped them to feel confident in their abilities in classification of living organisms when game-based learning approach was used to deliver the lesson. However, 2 respondents disagreed and 2 respondents strongly disagreed respectively that game-based learning approach helped them to feel confident in their abilities in classification of living organisms when game-based learning approach was used to deliver the lesson.

Table 1b: Perception of Teacher Trainees on the Use of Game-based Learning Approach in Teaching and Learning of Classification of Living Organisms

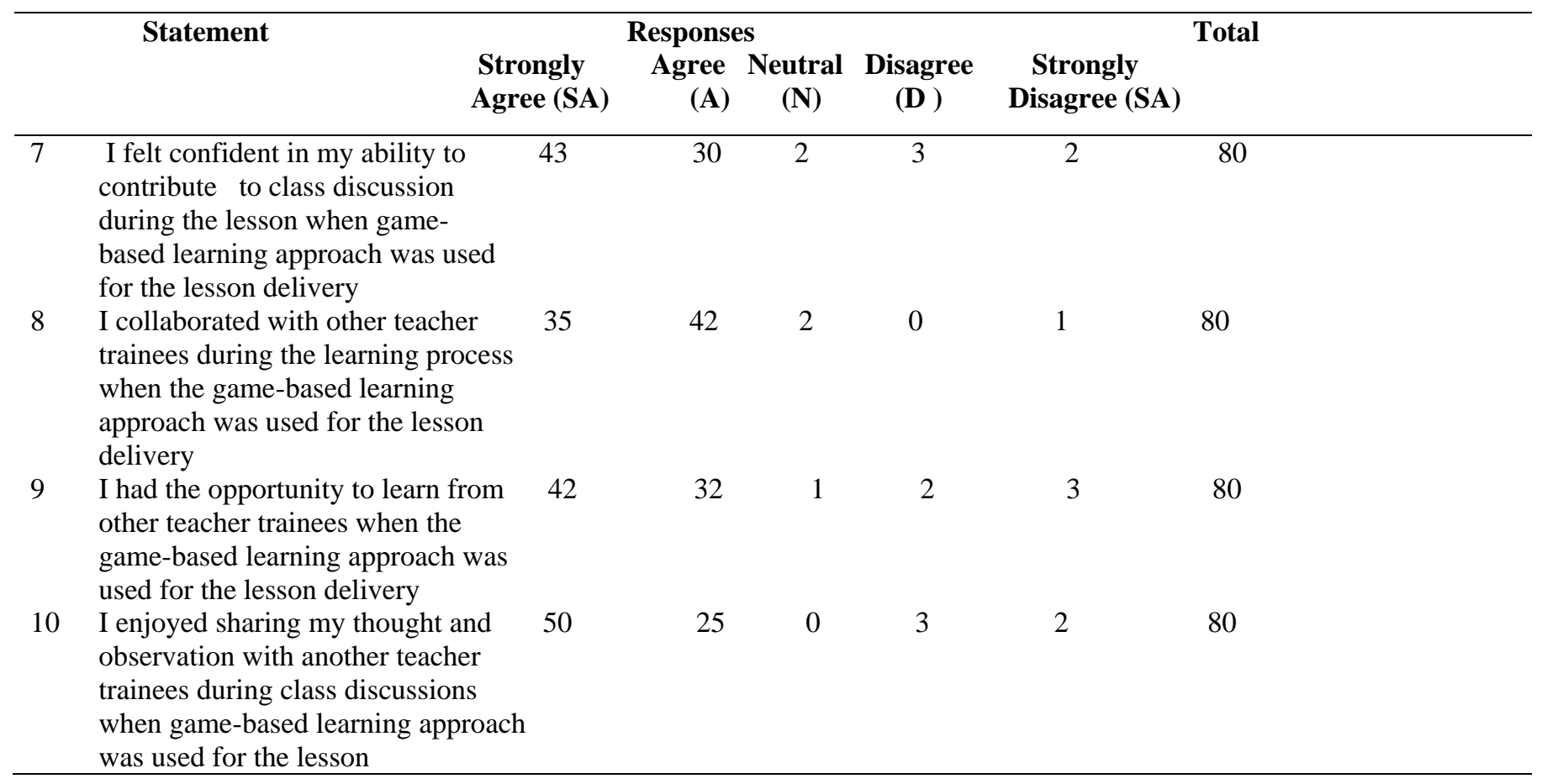


It is also clear from Table $1 \mathrm{~b}$ that, 43 respondents strongly agreed that they felt confident in their ability to contribute to class discussion during the lesson when game-based learning approach was used for the lesson delivery. Also, 30 respondents agree that they felt confident in their ability to contribute to class discussion during the lesson when the game-based learning approach was used for the lesson delivery. 2 respondents responded neutral to the statement that they felt confident in their ability to contribute to class discussion during the lesson when the game-based learning approach was used for the lesson delivery whiles 3 respondents disagree and 2 respondent strongly disagree that they felt confident in their ability to contribute to class discussion during the lesson when the game-based learning approach was used for the lesson delivery.

Table $1 \mathrm{~b}$ reveals that 35 respondents strongly agreed that they collaborated with other teacher trainees during the learning process when game-based learning approach was used for the lesson delivery. 42 respondents agreed that they collaborated with other teacher trainees during the learning process when gamebased learning approach was used for the lesson delivery and 2 respondents remained neutral on whether they collaborated with other teacher trainees during the learning process when gamebased learning approach was used for the lesson delivery. However, no respondent disagreed and 1 strongly disagreed that they collaborated with other teacher trainees during the learning process when game-based learning approach was used for the lesson delivery respectively. The responses given above really suggest that the majority 77 of the respondents collaborated with each other during the learning process when the game-based learning approach was used for the lesson delivery. This assertion is supported by Green \& Bavelier, (2012) when they contended that social game-based learning platforms are increasing in popularity as they purport to enable students to reinforce knowledge and develop social and leadership skills, provides an opportunity for learners to apply acquired knowledge in groups.

The opinions of respondents on whether they had the opportunity to learn from other teacher trainees when game-based learning approach was used for the lesson delivery revealed that, 42 respondents strongly agreed and 32 respondents agreed that they had the opportunity to learn from other teacher trainees when game-based learning approach was used for the lesson delivery. Also 1 respondent neither strongly agreed, agreed, disagreed and strongly disagreed that they had the opportunity to learn from other teacher trainees when game-based learning approach technique was used for the lesson delivery. However, 2 respondents disagreed and 3 respondents strongly disagreed that they had the opportunity to learn from other teacher trainees when game-based learning approach was used for the lesson delivery. From the above analysis, the majority 74 of the respondents confirmed that they had the opportunity to learn from other teacher trainees when the game-based learning approach was used for the lesson delivery. This view is in line with the assertion of Kapp, (2012) \& Sheldon, (2012) when they said that game allows for increasing involvement of students and are efficient in overcoming significant deficits of traditional teaching methods as shown in the literature review.

Table $1 \mathrm{~b}$ again reveals that, 50 and 25 respondents respectively strongly agreed and agreed that they enjoyed sharing their thoughts and observations with another teacher trainees during class discussion when the game-based learning approach was used for the lesson delivery respectively. Also, no respondent responded neutral on the above assertion. However, 3 and 2 respondents disagreed and strongly disagreed respectively that they enjoyed sharing their thoughts and observations with another teacher trainees during class discussion when the game-based learning approach was used for the lesson delivery.

Thus, the responses gathered from the majority 75 , of the respondents confirmed the assertion of Hurlock (1978) that a game is a process of physical or physic activity that is fun and enjoyable, hence its use in teaching and learning of science will enable students to enjoy concepts and facts being presented in the subject.

\section{RESEARCH FINDINGS}

From the analysis in Table 1a, it came to light that, out of 80 teacher trainees who were taught by the use of game-based learning approach;

- 71 respondents were of the view that game-based learning approach motivated and engaged them during teaching and learning process.

- 72 of the respondents indicated that game-based learning approach provided immediate feedback to them.

- 76 of the respondents confirmed that game-based learning approach helped them to develop social and physical skills simultaneously.

- $\quad 74$ of the respondents affirmed that game-based learning approach enabled them to learn with fun when it was used during the teaching and learning process.

- 76 of the respondents confirmed that their interest was increased when game-based learning approach was used during teaching and learning process.

- 76 of the respondents were of the view that they felt confident in their abilities in the topic taught when gamebased learning approach was used during teaching and learning process.

It is also evident from the analysis in Table $1 \mathrm{~b}$ that,

- 73 of the respondents felt confident in their abilities to contribute to class discussion during the lesson when game-based learning approach was used during teaching and learning process.

- 77 of the respondents were of the view that they collaborated with other teacher trainees when gamebased learning approach was used during teaching and learning process.

- 74 of the respondents had the opportunity to learn from other teacher trainees when game-based learning approach was used during teaching and learning process.

- $\quad 75$ of the respondents enjoyed sharing their thoughts and observations during class discussions when game-based learning approach was used during teaching and learning process.

These findings are in agreement with Studies by Garris, Ahlers, \& Driskell (2002); Garzotto (2007); Hill (2006); Lieberman (2001); Sugimoto (2007); Virvao (2005); when they opined that using educational games as a learning approach 
promote the holistic learning of students including cognitive, affective as well as psychomotor skills; motivate and excite students; offer immediate feedback; support skills; influences changes in behavior and attitudes which improve their attention span and keeps them engaged in the educational activities with full vigour.

\section{CONCLUSION AND RECOMMENDATION}

The results obtained from this study are sufficient to conclude that teacher trainees: were motivated and engaged; received immediate feedback; developed social and physical skills simultaneously; learnt with fun; interest was increased; felt confident in their abilities in the topic taught; felt confident in their abilities to contribute to class discussion; collaborated with other teacher trainees; had the opportunity to learn from other teacher trainees; enjoyed sharing their thoughts and observations during class discussions when game-based learning approach was used during teaching and learning process.

In the light of these findings, it is important that creative approaches such as game-based learning approach game-based learning approach should be adopted by science tutors in Colleges of Education for effective teaching and learning since they; motivate and engage, provide immediate feedback, develop social and physical skills simultaneously, help students to learn with fun and increase students interest and confidence level.

\section{APPENDIX A}

\section{Lesson Plan Activities}

Educational games were used by the researcher to teach to 'Classification of Living Organisms'. In all, the whole lesson was taught in two weeks made up of 12 hours. Thus 6 hours was used to teach the participants in each group the same topic on classification of living organisms. When designing the games, particular attention was paid to the General Biology Course objectives and the appropriateness of the game to the students' level. The educative card game "Taxa-Find-Match" and descriptive game "Classify It" were used.

\section{Rules on how to play 'Taxa-Find-Match'}

1. spreading the set of cards face down on a table.

2. Select any two cards that matches

3. If the cards matches for example, one has a picture of an animal (frog) and the other is a card that says "have smooth skin with no fur or scales; live on land but lay eggs with no shells in wet places; breath in air through lungs; some have gills at a certain stage of their life cycle, the matched pairs are correct, and the player keeps the pair of cards

Also, names of some scientist like Aristotle and Carolus Linneaus were written on one card and their contributions in classification of living organisms were also written on another card to enable participants to match them in the game. Again, some terminologies like Taxonomy, Binomial nomenclature and Classification were also written on cards and their corresponding meanings on another card for participants match.

The researcher observed the students' behaviours and supervised as they played the game. The achievement test, which was previously administered as pre-test, was re-administered as post-test to both game-based learning approach treatment group and think-pair-share learning technique treatment group under the same conditions. In addition, the questionnaire guides on the perception of teacher trainees on the use both game-based learning approach and think-pair-share learning technique was administered to both game-based learning approach treatment group and think-pair-share learning technique treatment group to examine the effectiveness of the intervention put in place.

\section{Description of the games}

To use "Taxa-Find - Match" game to reinforce the students" understanding on classification of some plants and animals; their properties and their use in everyday life, the researcher prepared a set of pairs of matching cards. In each pair, there is a picture on one card and a word statement on the matching card. The researcher explained to the teacher trainees on how to play the game of picture and property cards.

\section{Activity one}

Teacher trainees were asked to play the game in groups, first spreading the set of cards face down on a table. Teacher trainees took it in turns, turned over a picture card, showed to the class to be noted and placed it on the table with face up. The group then looked for its corresponding characteristics on another card. If the cards match e.g., one has a picture of an animal (frog) and the other is a card that says 'lives on land and water (amphibian)', the matched pairs are correct, bingo sound was pronounced and the player keeps the pair of cards and if the pairs do not match, the player has to turn the cards face down without the bingo sound being said. The next player then takes their turn and does the same. Students were asked to gather as many matched pairs as possible. As they played, the researcher moved from group to group to see how they were managing. The winner in each group was the person with the most complete matched pairs. At the end of the lesson, teacher trainees were asked to copy and complete a table about grouping plants and animals according to properties.

\section{Activity two}

On the use of "Classify It!" Students were asked in their groups to mention two names of animals or plants and use the taxonomic hierarchy proposed by Carl Linnaeus to classify them by using their smartphones to assess information online and state where they can be found. The students were expected to provide a variety of names of plants, animals and their habitats as possible. Clues on how to describe plants and animals, and their habitats were provided for students to follow. The teacher trainees then played the game 'Classify It' by matching correctly the named species of animals or plants to their proper kingdom, phylum/division, class, order, family, genus and species and their habitats, within a given period of time. A group that completed the task within the time limit, pronounce the sound "bingo!" and the group members had to do presentation for the class to critique and marks awarded to the group.

After the presentations the winner was declared based on the involvement of the participants in the group, the time it took to complete the game and the ability of the group to consolidate the new information acquired by stating the characteristics of species of plants and/or animals they have learnt while playing the game. 


\section{Activity three}

After the lesson, a questionnaire on game-based learning approach were administered to solicit the views of teacher trainees on the use of game-based learning approach.

\section{APPENDIX B QUESTIONNAIRE GUIDE FOR TEACHER TRAINEES' ON GAME-BASED LEARNING APPROACH}

\section{Perception of Teacher Trainees' on the extent to which Game -Based Learning Approach improves their Performance}

This instrument has been rated on a five-point close-ended Likert-type items: Strongly Agree (SA), Agree (A), Neutral (N), Disagree (D) and Strongly Disagree (SD).

Please tick the answer that corresponds to your preferred response.

\begin{tabular}{|c|c|c|c|c|c|c|}
\hline $\mathrm{S} / \mathbf{N}$ & ITEM & SA & $\mathbf{A}$ & $\mathbf{N}$ & D & SD \\
\hline 1 & $\begin{array}{l}\text { Game-based learning } \\
\text { motivated and engaged me } \\
\text { during teaching and learning } \\
\text { process }\end{array}$ & & & & & \\
\hline 2 & $\begin{array}{lr}\text { Game-based } & \text { learning } \\
\text { provided } & \text { immediate } \\
\text { feedback to me } & \end{array}$ & & & & & \\
\hline 3 & $\begin{array}{l}\text { Game-based learning helped } \\
\text { me to develop social and } \\
\text { physical } \\
\text { simultaneously }\end{array}$ & & & & & \\
\hline 4 & $\begin{array}{l}\text { Game-based learning } \\
\text { enabled me to learn with fun }\end{array}$ & & & & & \\
\hline 5 & $\begin{array}{l}\text { Game-based learning } \\
\text { increased my interest in the } \\
\text { lesson }\end{array}$ & & & & & \\
\hline 6 & $\begin{array}{l}\text { I felt confident in my } \\
\text { abilities in the topic taught } \\
\text { when game-based learning } \\
\text { approach was used for the } \\
\text { lesson delivery }\end{array}$ & & & & & \\
\hline 7 & $\begin{array}{l}\text { I felt confident in my ability } \\
\text { to contribute to class } \\
\text { discussion during the lesson } \\
\text { when the game-based } \\
\text { learning approach was used } \\
\text { for the lesson delivery }\end{array}$ & & & & & \\
\hline 8 & $\begin{array}{l}\text { I collaborated with other } \\
\text { teacher trainees during the } \\
\text { learning process when the } \\
\text { game-based learning } \\
\text { approach was used for the } \\
\text { lesson delivery }\end{array}$ & & & & & \\
\hline 9 & $\begin{array}{l}\text { I had the opportunity to learn } \\
\text { from other teacher trainees } \\
\text { when the game-based } \\
\text { learning approach was used } \\
\text { for the lesson delivery }\end{array}$ & & & & & \\
\hline
\end{tabular}

\begin{tabular}{|c|c|}
\hline 10 & $\begin{array}{l}\text { I enjoyed sharing my } \\
\text { thought and observation with } \\
\text { teacher trainees during class } \\
\text { discussion when the game- } \\
\text { based learning approach was } \\
\text { used for the lesson delivery }\end{array}$ \\
\hline
\end{tabular}

\section{REFERENCES}

[1] Andang, I. S. (2006). Education Games: Being Smart and Cheerful with Educational Games. Yogyakarta: Media Pillar. Indonesia.

[2] Anyanwu, C. C. (2014). Exploring Students' Experiences of Information and Communication Technology (ICT) Facilitated Feedback: A case study of business management education students at a higher institution in KwaZuluNatal.

[3] Bhoopathi, P., Sheoran, R. \& Välimäki, M (2006). Educational games for mental health professionals. Cochrane Database of Systematic Reviews, 2 (2), 23-33.

[4] Boctor, S. (2012). ABC's of Parenting: 26 practical lessons for building a healthy and happy home. Mobile, AL: Everygreen Press.

[5] Bradshaw, M. J. \& Lowenstein, A. J. (2007). Innovative Teaching Strategies in Nursing. (4th ed.). Sudbury: Jones and Bartlett.

[6] Fuszard, B. (2001) Gaming. In Lowenstein, A. J., Bradshaw, M. J. \& Fuszard, B. (Eds.) Fuszard's innovative teaching strategies in nursing (3rd ed.). Gaithersburg, MD, Aspen Publishers.

[7] Garris, R., Ahlers, R. \& Driskell, J. E. (2002). Games, Motivation, and Learning: A Research and Practice Model. Simulation and Gaming, 33(4), 441-467.

[8] Garzotto, F. (2007). Investigating the Educational Effectiveness of Multiplayer Online Games for Children. Paper presented at the Interaction Design and Children (IDC 2007), Aalborg, Denmark.

[9] Gee, J. P. (2008). Being a Lion and Being a Soldier: Learning and Games. In J. Coiro, M. Knobel, C. Lankshear, \& D. J. Leu (Eds.), Handbook of research on new literacies (pp. 1023- 1036). New York, NY: Lawrence Erlbaum.

[10] Green, C. S. \& Bavelier, D. (2012). Learning, Attentional Control, and Action Video Games. Current Biology, 22 (6), R197-R206.

[11] Haggart, J. (2001). Walking ten feet tall. Sheffield: Department for Education and Skills.

[12] Hill, J. (2006). Impacts of playing video games on learning in children. Literature Synthesis for Applying Research. Retrieved from jinayang.myweb.uga.edu/edit6900/resources/report.pdf

[13] Hughes, J. (1999). Altered states: Creativity under the influence. New York: Watson-Guptill Publications.

[14] Hurlock, E. B. (1978). Child growth and development. New York: Webster Division, McGraw-Hill.

[15] Ibrahim, R., Yusoff, R. C. M., Omar, H. M. \& Jaafar, A. (2011). Students Perceptions of Using Educational Games to Learn Introductory Programming. Canadian Center of Science and Education, 4(1), 205-216.

[16] Jenkins, H., Klopfer, E., Squire, K. \& Tan, P. (2003). Entering the education arcade. Computers in Entertainment, 1(1), 17-17.

[17] Kapp, K. M. (2012). The Gamification of Learning and Instruction. San Francisco: Pfeiffer.

[18] Kim, B., Park, H. \& Baek, Y. (2009). Not just for fun, but serious strategies: Using meta-cognitive strategies in game-based learning. Computers and Education, 52, 800-810.

[19] Lieberman, D. A. (2001). Management of Chronic Pediatric Diseases with Interactive Health Games: Theory and Research Findings. Journal of Ambulatory Care Management, 24(1), 26-38.

[20] Sheldon, L. (2012). The Multiplayer Classroom. Boston: Course Technology.

[21] Sugimoto, M. (2007). What can Children Learn through Game-based Learning Systems. In 1st IEEE International Workshop on Digital Game and Intelligent Toy Enhanced Learning (DIGITEL '07). IEEE: Xplore.

[22] Virvao, M. K. G. (2005). Combining Software Games with Education Evaluation of its Educational Effectiveness. Educational Technology \& Society, 8(2), 54-65. 
[23] Webb, T. P., Simpson, D., Denson, S. \& Duthie Jr, E. (2012). Gaming used as an Informal Instructional Technique: Effects on Learner Knowledge and Satisfaction. Journal of Surgical Education, 69(3), 330-334.

[24] Wright, W. (1894). A Short history of Syriac literature, by the late William Wright. London: Adam and C. Black.

\section{AUTHORS}

First Author - Joseph Parker, Enchi College of Education, P. O. Box 44, Enchi. W/R- Ghana., kerpack@yahoo.com Second Author - Valentina Osei-Himah, Atebubu College of Education, P. O. Box 29, Atebubu. B/A, oseihimah@yahoo.com 